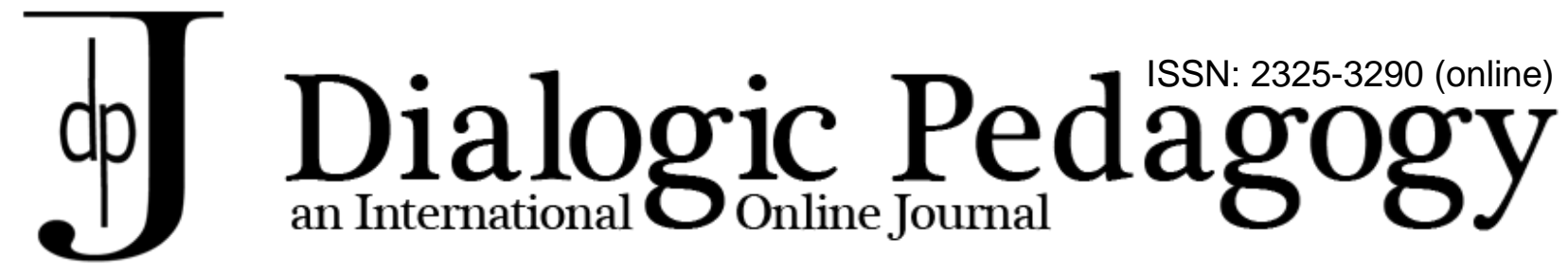

\title{
Dialogic action in climate change discussions: An international study of high school students in China, New Zealand, Norway and the United States
}

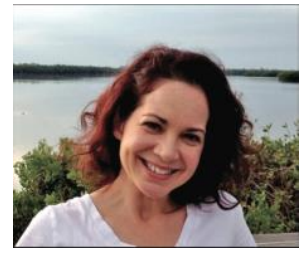

Diana J. Arya

University of California, Santa Barbara

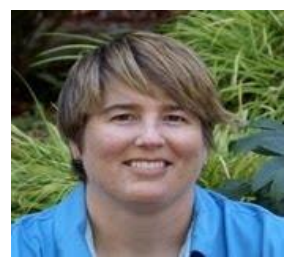

Jessica K. Parker

Sonoma State University

\begin{abstract}
Global efforts to prepare young developing minds for solving current and future challenges of climate change have advocated interdisciplinary, issues-based instructional approaches in order to transform traditional models of science education as delivering conceptual facts (UNESCO, 2014). This study is an exploration of the online interactions in an international social network of high school students residing in Norway, China, New Zealand and the United States (N=141). Students participated in classroom-based and asynchronous online discussions about adapted versions of seminal scientific studies with facilitative support from seven scientists across various fields. Grounded in a language-in-use frame for investigating facilitation and demonstrations of problem-based and evidence-based reasoning (Kelly \& Chen, 1999), we traced the varied questions, assertions, and evidentiary sources within student-led online discussions. We found that questions from scientific experts in the form of unconstrained, open-ended invitations for exploration were followed by students' acknowledgement and consideration of complex and, at times, conflicting sociopolitical and economic positions about climate change issues. These findings suggest that broadening science classroom discussions to include socially relevant, unsolved issues like climate change could open potential entry points for a dialogic approach that fosters a scientific community in the classroom.
\end{abstract}

Key Words: Science education, digital literacy, dialogic practices

Diana J. Arya is currently an assistant professor at the University of California, Santa Barbara. Her research interests include digital literacy practices and fostering collaborative learning and discussions among adolescent students from various cultural backgrounds.

Jessica K. Parker is associate professor in the School of Education at Sonoma State University. Parker studies how secondary schools integrate multimedia literacy into academic literacy learning. Her areas of emphasis include new literacies, educational technology, new media studies, and gender studies.

$\cos 0300$

\section{Introduction}

At this potentially critical moment for human civilization, it is imperative that people, organizations, and governments be given the resources they need to participate in constructive civic, commercial, and personal decision-making about climate change risks and solutions. (Bowman et al., 2010) 


\section{Dialogic action in climate change discussions: An international study of high school students in China, New Zealand, Norway and the United States}

Diana J. Arya \& Jessica K. Parker

Dialogue with the people is radically necessary to every authentic revolution. (Freire, 1970, p. 128.)

The United Nations Educational, Scientific and Cultural Organization (UNESCO) has claimed the past ten years as the "Decade of Education for Sustainable Development" (DESD) in efforts to elevate the issues of long-term, environmental sustainability in learning communities all around the world (Buckler \& Creech, 2014; Wals, 2012). Moving beyond notions of education as teaching knowledge and principles, the DESD framework for classroom learning emphasizes the need for teachers to foster student engagement in "the complexities, controversies and inequities rising out of issues relevant to environment, natural heritage, culture, society and economy" (Wals, p.12). This framework aligns with the "excerpted messages" above; real changes in the ways that people think about and act on the Earth's changing climate and available natural resources requires an open dialogue that is inclusive of varying sources of knowledge and experience. Climate change scientists like Bowman et al. (2010) demand that citizens consider the evidence for and life-threatening consequences of the Earth's changing climate in order to take an active, decision-making role in discussions about climate change mitigation policies and practices. Freire's (1970) words complement this sentiment about what should be considered with the how; any major changes in the ways that communities, organizations and institutions operate are impossible without open and honest dialogue. Similarly, UNESCO is calling for educational practices that foster the engagement in sustainability issues that is more than understanding conceptual information and processes. As such, traditional models of science instruction in the form of delivering conceptual facts are insufficient for fostering engagement with issues about an uncertain future. In their most recent report, UNESCO emphasized the importance of providing opportunities for students to consider the tensions created from the intersections of lifestyle consumption and green technologies (Buckler \& Creech, 2014). For such an open dialogue about the consequences of climate change on living beings within ecosystems around the world to occur in the science classroom, students need the time and space to initiate and engage in problem-based and evidence-based reasoning about climate change. Such reasoning requires that students have the opportunity to question, challenge, and co-construct ideas and claims. This form of dialogue is what we characterize as dialogic action.

Our schools are called to contribute to DESD efforts in raising societies equipped to address a continually changing climate with limited natural resources, yet it is unclear what specific pedagogical practices promote this form of dialogic action as a way of fostering awareness and engagement in complex issues (Benavot, 2014; Fien, 2012). This call for dialogic action has arrived during the everevolving digital age of multiliteracies that involve linguistically and technologically diverse forms of communication, including online discussions (e.g., Hafner \& Miller, 2011; Luke, 2008; Mills, 2009). Our study is an exploration of virtually posted discussions initiated by questions and issues related to global climate change (e.g., threats to biodiversity) within an international project for secondary students living in China, New Zealand, Norway, and the United States $(\mathrm{N}=141)$. Based on a view of learning as sociocultural practices in argumentation (Kelly \& Chen, 1999), we traced the communicative turns in online discussions initiated by student participants and facilitated by seven scientists across the fields of biology, physics, and environmental studies. With particular interest in the expert-facilitated conversational moves to foster the dialogic action (defined here as student-led, posted discussions that invite problem-based and evidence-based reasoning that involves questioning, challenging, and coconstructing ideas and claims), we explore the pedagogical moves and subsequent interactions within a series of discussion forums in order to answer the following research questions:

1. Which assertions (questions, suggestions, etc.) from participating facilitators (the consulting scientists) were taken up by the students? 


\section{Dialogic action in climate change discussions: An international study of high school students in China, New Zealand, Norway and the United States}

Diana J. Arya \& Jessica K. Parker

2. How did the assertions from the facilitators support (or constrain) the shared reflections, disagreements, affirmations, and creations of understanding of the student participants?

We employed a two-step discourse analysis of online discussions, using other related data sources (pre- and post- interview responses) for clarifying and/or confirming analytic claims, to address these research questions within a discourse-based frame of dialogic action.

\section{Dialogic Pedagogy for a Global Virtual Community}

Students are increasingly provided with the necessary technologies for engaging in discourse with others beyond the classroom walls, to engage in dialogue about shared interests or learning goals in virtual space (Blake, 2013; Collins \& Halverson, 2009; Wegerif et al., 2010). As such, teachers are increasingly provided with the opportunities to foster a global community of students through the use of available wikispaces, chat rooms, online forums, etc., that are designed to provide a space for members to share, reflect, disagree, affirm, learn, and create. This vision of pedagogy has been widely supported by researchers and scholars across disciplines who tout the use of virtual spaces for broadening and fostering dynamic and meaningful interactions and learning (Anderson, 2008; Bellanca \& Stirling, 2011; Hoadley \& Enyedy, 1999; Richardson \& Swan, 2003; Rovai \& Jordan, 2004; Wertsch, 2002). However, the availability of the virtual space does not, on its own, ensure dialogic communication among its members (Kop, 2011; Krejins, Kirschner \& Vermeulen, 2013; Massey, 2003; Rourke \& Kanuka, 2007). For example, participants in a wikispace may not even be aware of the idea that they are members of a community (Beth et al., 2013). Further, these participants may not be compelled to engage with others in the kind of online discourse required for questioning and co-constructing ideas about a given academic topic or issue (Cho, Lee \& Jonassen, 2011; Hoskins \& Van Hooff, 2005). Teachers in turn may not be prepared to foster online discussions at such a deep level (Beth at al., 2013; Hernandez-Ramos, 2004). Exchanges involving problem-based and evidence-based reasoning that includes questioning, challenging, and co-constructing knowledge reflect UNESCO's vision for DESD-based education and, in turn, serve as our vision of dialogic action for this study.

\section{The dialogic nature of scientific reasoning.}

Learning practices have long been viewed as social acts; the need for students to exchange ideas and co-construct meaning in order to develop linguistic and conceptual knowledge has been welldocumented in literacy research (Bazerman, 1982; Bomer \& Bomer, 2001; Gee, 1996; Gutierrez, Baquedano-Lopez \& Tejaeda, 1999; Hicks, 1996; Lewis, 2001). The socially dependent nature of issues like global climate change further heightens the need for open, thoughtful interactions among our student population about these critical issues (Luke \& Woods, 2009; Mendelsohn, 1977). Yet, too often students spend most of a science class period responding to discrete questions about conceptual facts from lectures and textbooks, leaving little or no opportunities for thoughtful and critical dialogue about the relevance and significance of targeted conceptual information (Ackerson \& Abdi-El-kalick, 2005; Latour, 1987; Lederman, 1992). Traditional science classroom notions of the scientific method, for example, have been criticized for demonstrating a narrow view of science; the contrived steps of inquiry oversimplify the complex and dynamic process of science and the conceptually oriented models that are employed by scientists across various fields (Abd-El-Khalick et al, 2004; Cartwright, 1983; Giere, 1988; Nersessian, 1999). This bleak picture of school science learning is encased in the general criticism of classroom teaching across the curricula as little more than a transmission of knowledge from the teacher as authority figure to the students as a passive audience (Anton, 1999; Adair-Hauck, Donato \& Cumo, 1994; Freire, 1970; Scott, 1998). 


\section{Dialogic action in climate change discussions: An international study of high school students in China, New Zealand, Norway and the United States}

Diana J. Arya \& Jessica K. Parker

The extensive literature on classroom talk across multiple disciplines has consistently revealed that teachers produce the majority of talk in classrooms, much to the detriment of student learning (e.g., Sampson \& Clark, 2009; Flanders, 1970; Zander, 2003). Instead of being passive receptacles of factual information, students must be able to talk in order to learn, especially within the science classroom (Lemke, 1990; Scott, 1998; Sutton, 1996). Thus, this study is a telling case about the affordances of online interactions for facilitating dialogic action as student participants engage in the sociopolitical and economic complexities of global climate change.

A well-documented application of dialogic theory is Mortimer and Scott's (2003) work on meaning making in science classroom discussions. These researchers highlight the importance of talk that includes varying viewpoints for challenging conceptual understanding. As students are given opportunities to express their ideas about the targeted concepts, they engage in an iterative cycle of revision and meaning co-construction. This view of dialogic action emphasizes the multi-voiced, contentious nature of discursive acts (Bakhtin, 1930s; 1981) and the socially and culturally situated nature of learning (Vygotsky, 1978; Wertsch, 2002). Mortimer and Scott have demonstrated how dialogic action (defined within their work as consensus building about conceptual knowledge) is facilitated within a classroom; however, investigations of dialogic action within online spaces shared by multiple classrooms around the world have yet to be conducted.

\section{Dialogic action in online discussions.}

Collaborative online learning has been characterized as dialogic in nature; that is, such learning involves the interactions of multiple voices that are at times conflicting, and these conflicting positions are in turn necessary ingredients for critical reasoning (Enyedy \& Hoadley, 2006; Wegerif, 2006, 2011). Further, the online quality of these interactions releases participants from the traditional constraints of who and when in classroom discussions in that users are able to post their ideas, disagreements, affirmations, and experiences without first being recognized by the community or competing with other potential contributors to share within a limited time frame. Although some confusion may occur in such an exchange, the overflow of responses to an initiated topic, question, opinion, or reported experience can also increase the opportunity for deeper reflection and learning (Bell, 1997; Cohen \& Scardamalia, 1998; Hoadley \& Linn, 2000; Schellens \& Valcke, 2005; Wegerif, 2004).

The importance of incorporating dialogic, online learning into classroom practices rests on mounting research illustrating the positive results (e.g., increasing open dialogue and collaboration among students) when students are able to freely discuss subject matter in virtual space rather than the limited time and space of traditional classroom discussions. Empirical studies on the educational benefits of increased critical reasoning and argumentation via online communication have surfaced in recent years (Cress \& Kimmerle, 2008; Larusson \& Alterman, 2009; Mak \& Coniam, 2008; Nussbaum et al., 2007; Pifarre \& Staarman, 2011; Wegerif, 2006; Wheeler, Yeomans \& Wheeler, 2008). Pifarre and Staarman, for example, examined the online collaborative practices of 25 primary students (ages 9 to 11 years of age) in Spain, and found that online discussions within a wiki environment facilitated an open dialogue with greater frequency of student talk that led to co-constructed texts and shared new understandings. Similarly, Larusson and Alterman found in their two case studies of university students that a wiki environment may be a supportive element for collaborative activities, which often require time and space beyond the typical boundaries of a classroom. In this sense, online collaboration enables participants to "change their minds, to question their own positions, and to ask for help when they did not know the answer" (Wegerif, 2006, p. 150). 


\section{Dialogic action in climate change discussions: An international study of high school students in China, New Zealand, Norway and the United States}

Diana J. Arya \& Jessica K. Parker

In this study, we seek to contribute to scholarly work on online learning by exploring how dialogic action is facilitated (or inhibited) within issues-based discussion forums initiated by a network of high school students who reside in four different countries. Using a classroom discourse frame for analyzing language in use within a secondary school science context (Kelly \& Chen, 1999), we explored the social turns within online discussions that were designed (along with classroom-based materials and activities) to address the three general themes highlighted by the working groups of the Intergovernmental Panel on Climate Change (IPCC, 2010)-a) The Physical Science Basis of Climate Change, b) Climate Change Impacts, Adaptation and Vulnerability, and c) Mitigation of Climate Change. In addition to descriptions of participant and site-level contributions to these online discussion threads, we investigated the particular linguistic and social cues that indicate a sense of membership and the ways in which members engage in problem-based or evidence-based reasoning, with particular emphasis on the contributions of the consulting scientists for facilitating these engagements in reasoning. Patterns identified in the facilitative moves of the consulting scientists may inform a theory for fostering the dialogic action needed for environmental awareness and sustainability around the world (Buckler \& Creech, 2014). Further, this approach may be useful for fostering dialogic action within other disciplines of study.

\section{Method}

\section{Participants and Setting}

A total of 141 high school students (14-17 years of age), participated in Climate Exchange for Language and Learning (CELL), which was an eight-week program designed for collaborative, evidencebased discussions related to global climate change issues. The participants from China $(n=30)$ attended a boarding school located in one of the largest cities in the southern region of the country. The participants from New Zealand $(n=25)$ attended an urban high school in the southern tip of the northern island. The participants from Norway $(n=32)$ attended a performing arts high school in a large city in southern Norway. Whereas the three previously mentioned groups were single class settings, participants from the United States $(n=54)$ were made up of two separate science classes, only one of which $(n=28)$ completed the pre- and post- surveys and interviews. Both groups of U.S. participants attended the same suburban high school in northern California.

All participating classrooms devoted an average of two hours of weekly class time for CELLrelated activities over the eight-week period. The number and duration of daily CELL activities depended on scheduling constraints of each participating classroom. Participants were also encouraged (but not obligated) to devote time outside of school hours to engage in online activities related to CELL.

\section{Instructional Context: CELL Program}

The central focus of the CELL program was to provide the structures necessary for an open and honest cross-national exchange about the scientific evidence related to five issues considered most critical to global climate change (Gleick et al., 2010): rise in temperature; rise in sea level; humaninduced greenhouse effect; loss in biodiversity; deforestation. Compared to school science topics such as electromagnetism or photosynthesis, climate change has a greater socio-political relevancy and thus, in our opinion, increased the potential for productive exploratory talk among the participants. Online exchanges were by design initiated by participating students who were encouraged by teachers and researchers to construct and post questions to an online platform. Moodle, an open-source learning management system, provided a secure and private site for students to engage in asynchronous activities and access project-related resources. 


\section{Dialogic action in climate change discussions: An international study of high school students in China, New Zealand, Norway and the United States}

Diana J. Arya \& Jessica K. Parker

The Moodle platform provided a space for student participants to build upon the classroom discussions about the targeted climate change issues. Within this platform, participants entered a discussion forum about a particular climate change topic by selecting the corresponding forum prompt: Post your group's questions regarding (climate change issue) and respond to your peers' posts. These forum prompts were open-ended in order to encourage students to ask questions that they had about the topic. In addition to the discussions, the Moodle platform was a source for a collective glossary, various brief surveys and games, and member profiles.

Initial questions posted by students were in turn read, considered, and responded to by participating peers, researchers, teachers and consulting scientists. The overarching structure of the CELL program was inspired by earlier initiatives in collaborative online science learning by Slotta and colleagues, who have found that online collaboration among peers can have a positive effect on engagement and understanding (e.g., Stagg Peterson \& Slotta, 2009; Slotta \& Aleahmad, 2009; Slotta \& Linn, 2009). The unique components of the CELL program included the use of adapted seminal scientific studies, which participants read and discussed in their respective classrooms as well as within secure, online discussion forums, chats, and blogs. Another unique aspect of CELL was the inclusion of seven scientists across a variety of fields (biology, physics and environmental studies) who were recruited to facilitate the online discussions.

Educational researchers from neighboring universities facilitated the CELL-based activities in the four respective research sites. Participants read, researched, and discussed a variety of texts including adapted versions of original scientific research, video clips from news programs and public service websites, and digital images. The primary language of all CELL activities and materials was English.

Online discussions in the CELL program began with a posted question by one student or a small group of students. The formation of these questions was influenced by classroom readings and discussions as well as events and experiences outside the classroom. Within the classroom, students read and discussed the relative importance of scientific data that suggested a significant change in the Earth's climate. These data were presented in the form of individual study abstracts of seminal published articles about one of the five targeted climate change issues. Students were encouraged to discuss the practical significance of these readings in light of their own knowledge and experiences, thus allowing for a fluid exchange of ideas that vary in formality and conceptual focus. The lead teacher also prompted students to consider what questions they would like to post to the online platform. Students were then encouraged to post their questions online and engage in discussions with students from other participating classrooms. However, it was explained to all students that unlike the classroom activities and some of the online tasks (e.g., pre- and post-surveys) that were completed within the classroom period, there was no obligation to contribute to the discussions that generally occurred outside of school hours. Our decision to confine obligatory activities to in-school contexts aligned with established school-based guidelines for three of the four research sites.

Seven scientists from a variety of fields agreed to act as consultants for this program. The scientists as well as the lead teachers were encouraged to provide only solicited information and to post questions that would challenge the students' thinking (e.g., Do you think that these results are compelling? What do you think we still need to know? How do the data tell us that ...). Only the first letter of the students' last names was published in the online platform, and the distinguishing feature for scientists and researchers was that their full names were presented. Participants, including students, were able to view the profile of each contributor by clicking on the featured name, which was displayed next to a self-created avatar picture. 


\section{Dialogic action in climate change discussions: An international study of high school students in China, New Zealand, Norway and the United States \\ Diana J. Arya \& Jessica K. Parker}

All texts and classroom activities within the CELL program were designed to provide linguistic and conceptual support for the online discussions as well as to maximize the online communication between students and consulting scientists. As such, classroom-based discussions provided student participants with the opportunity to reflect on and co-construct questions, assertions, or claims that they deemed most relevant to the targeted climate change issue.

\section{Reading Materials}

Excerpted seminal scientific studies were introduced and discussed within the respective classroom sites and thus served as anchors for the ensuing online discussions. CELL participants read a total of 12 abstract studies, one or two pages in length, which were referenced by the IPCC (2010). The selected original studies were modified according to text length and cohesion of structural components (i.e., introduction, methods, results, and discussion) while maintaining original tables and figures. All abstracted studies and associated discussion questions were vetted by participating scientists, educators, and previewed by a classroom of Norwegian students $(\mathrm{N}=24)$ prior to the eight-week study. Figure 1 shows an excerpted text and illustration from a study by Church and White (2006) regarding the rise in sea level:

Australian geophysicists John Church and Neil White know that scientists have been studying the sea level since the mid 1800's, and wanted to use this recorded data as evidence to support their hypothesis that there has been a steady increase in sea level since the earliest recorded time until 2004.

Church and White used a special tool called a "tide gauge" in their own

observations of sea level, and this is a tool that has been used since the very beginning.

The following picture shows a tide gauge.

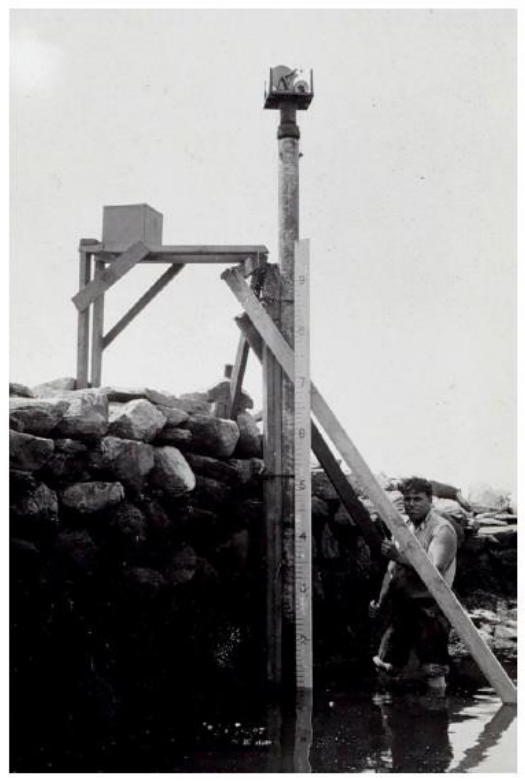

Figure 1. Example of excerpted scientific study.

The original versions of these study abstracts range according to climate change issue and date of publication. This cross-generational display of scientific work provided the opportunity for students to view and discuss the historicity of scientific investigations on a single issue such as the steady rise in sea 


\section{Dialogic action in climate change discussions: An international study of high school students in China, New Zealand, Norway and the United States}

Diana J. Arya \& Jessica K. Parker

level. Student participants read, evaluated, and reflected on reported processes and empirical data through in-person classroom discussions with immediate, country-specific peers and asynchronous computer-mediated communication with peers from the other research sites.

\section{Pre/Post Measures}

Participants responded to a series of online questionnaire items and individual interview questions before and after the CELL program in order to document individual change in conceptual knowledge and language use over time. The pre and post online questionnaire items (18 and 21 items respectively; the three additional post items targeted students' overall reflections of the program) were designed to elicit students' attitudes and beliefs about global climate change and their perceptions of the agreement within the scientific community regarding the changing climate (e.g., Do you believe that the Earth's climate is changing? Why or why not? What percentage of scientists do you think are confident that the Earth's climate is changing?).

A total of ten individual interview questions (conducted by researchers across the four sites) were asked prior to and after the study concluded. These questions elicited students' understanding of science, the work that scientists do, their definitions of global climate change as well as their understandings of scientific data presented in graphic form. All pre and post items from the interviews and online questionnaires were vetted and edited by researchers, scientists and the pilot class of students in Norway prior to program implementation. For this study, these responses served as ancillary sources of evidence for further clarifying patterns in the online exchanges. Specifically, responses to individual items, as previously exampled, were matched with online interactions involving the same participants; the additional data from survey and interview responses helped to clarify or confirm posted responses in the online forums.

\section{Analysis of Online Interactions}

The central focus of our analysis is the dialogic action within the discussion forums that were programmatically organized by specific climate change issues. Our approach for identifying and analyzing data sources involved a two-step process. First, we employed Kelly and Chen's (1999) language-in-use frame to identify key interactional events according to the design of the program and the context of learning science as problem-based and evidence-based reasoning. Our selection of this initiating frame of analysis is based on the similarity of Kelly and Chen's study, in which they investigated classroom interactions among high school physics students in order to make visible the ways in which discourse shapes a learning community. These educational scholars began their iterative cycle of inquiry by determining a taxonomy for organizing collected artifacts (classroom discussions, writing tasks, curriculum materials, etc.), which aligned with the local classroom units of study. The next phase of their analysis involved the creation of maps that traced moment-to-moment interactions within one of the identified units of archived data in order to determine the phases of an interaction leading to consensus. This grounded, participant-observer approach for identifying analytic units served as guide for selecting data sources and analytic units according to the organization of CELL events and activities. Just as author and science educator Kelly co-taught a conceptual physics course within a public high school in order to gain an insider's perspective of "science in the making" (p. 884), we were co-facilitators of the Norwegian and U.S. sites, which helped us to understand the ways student interactions facilitated understanding about climate change issues. Kelly and Chen's process of identifying and constructing data from available artifacts began with rich descriptions of discourse-related classroom routines and activities, including lab protocols, and writing assignments. These scholars then determined analytic units based on identified sources (e.g., collected written artifacts, lesson plans, recorded interviews and 


\section{Dialogic action in climate change discussions: An international study of high school students in China, New Zealand, Norway and the United States}

Diana J. Arya \& Jessica K. Parker

classroom activities) from a sequence of segmented activities that constituted a "cycle of activity" within a two-week period. Key discourse events from this cycle were identified, transcribed, and organized into thematically defined sequence units (e.g., conducting the experiment).

Following Kelly and Chen's logic of inquiry, we identified key data sources according to the design of the CELL program and the context of learning science as problem-based and evidence-based reasoning. Although the CELL online discussion activities were generally not a required component of program participation, we learned from site facilitators (including the Norwegian site teacher) that students were keenly interested in the online activity and would often refer to them during class discussions of seminal studies. As such, we used the students' perspectives about the online discussions as a guide for selecting the discussion threads for analysis. Threads that were discussed by the student participants were either topically framed (the one thread about the earthquake really showed that the Chinese are worried) or framed according to a particular activity (what can we do about . . ). Based on students' characterization of the discussion threads, we decided on a thematic (topic/activity) focus for our analysis of individual discussion threads. As such, our approach for categorizing units of analysis was grounded in a participant frame, which was followed by a closer inspection of the intentions and assertions within the bounded units.

Our initial step in identifying specific thematic categories for the discussion threads was to determine how climate change issues were organized within the aforementioned IPCC's (2010) working groups; as a guiding authority for the content of the CELL program, we suspected that the use of the working group themes would align with the themes of the online discussions. These themes are: a) The Physical Science Basis of Climate Change, b) Climate Change Impacts, Adaptation and Vulnerability, and c) Mitigation of Climate Change. We identified the use and prevalence of relevant constructs (e.g., aware(ness), change, ozone) and general summary ideas (e.g., a post focused on eliciting clarification about the natural process of the greenhouse effect) that facilitated the assignation of these thematic categories. In order to ensure accuracy in this categorization process, we categorized randomly selected portions of the posts separately and compared the initiating posts for each line of discussion. Intended meanings in all posted responses were clear enough to avoid any discrepancies in this categorization process.

The next phase of our analysis involved a closer inspection of the individual posts within the categorized discussion threads, taking note of communicative turns that signaled agreement (e.g., yes, I agree), disagreement (but that isn't the problem), or deictic indications of membership (we need to think about ways that we can ...; this is our problem). Analysis of specific asserted positions, contentions, and agreements within the discussion threads followed the general principles of Conversational Analysis (CA), which is defined as a method for observing and evaluating the intentions or shared understandings between individuals engaged in talk (Atkinson \& Heritage, 1984). CA is noted as an effective approach for conducting "in-depth examinations of the content, structures, processes, and meaning of on-line conversation" (Mazur, 2004, p.1095). Following such conventional thinking, CA served as a general guide for identifying structural features like indications of disagreement and questioning stances in online discussions (but, I disagree, and no, etc.) as well as assertions of agreement ( $I$ agree, yes, that also happened to me, etc.) that were focal points of analysis (Pomerantz, 1984; Sacks, 1987). Just as Kelly and Chen (1999) used sociolinguistic frames for identifying "contextualization cues" in classroom talk ( $p$. 895), we use the CA framework for identifying communicative cues signaling dialogic action in online discussions. In this sense, we were able to identify patterns across the thematically organized discussion threads. 


\section{Dialogic action in climate change discussions: An international study of high school students in China, New Zealand, Norway and the United States}

Diana J. Arya \& Jessica K. Parker

In accordance with standard practices in scientific methodology for ensuring validity of inferences (Budowle et al., 2009), we conducted separate analyses of the online discussions during both phases of the investigation. These separate analyses were then compared to one another for evidence of consistency in inferential claims about the discussion threads. As an additional check to the quality of our analysis, we recruited a scholar with an expertise in research methodology to conduct an external review of our analytic methods and data analysis. We achieved a high consistency in identified categories and communicative assertions; we had full consensus on the decision to thematically organize analytic units and $92 \%$ consistency of CA-guided analysis of disagreement, agreement, and evidence-based assertions across the three raters. The few discrepancies in discursive moves were discussed and resolved by achieving consensus across the three raters. Because assertions by raters required the open and explicit consideration of evidence from data sources, consensus was reached for each disagreement.

Interview transcripts, online survey responses, commentary from consulting scientists and participating teachers, and field notes by researchers were sources for a) contextualizing online discussions in order to present a clearer picture of the intended actions and values of active participants and b) triangulating data sources for supporting emerging theories about the ways in which contributors (particularly the scientific experts) facilitate (or inhibit) dialogic action within the online discussions. A total of 132 discussion threads (i.e., collection of posts) encompass 453 individual posts (310 of these posts are from students). Our analysis is focused on these discussion threads and excludes 46 initiated posts without responses. Approximately $32 \%$ (144 posts) were written by researchers or scientists. All other posts were from students.

None of the teachers posted a response, even though the researchers at each respective site explicitly invited teachers to join these exchanges. The teacher of the Norwegian classroom had expressed his interest in monitoring the students' online activities, but was reluctant to "interfere" with the exchange. The teacher of the California site expressed his overall skepticism of human-induced climate change, noting that this program was a way to address one component of his curriculum. The teacher of the Chinese site found the exchanges very interesting but felt more comfortable exchanging messages with the program coordinators. The teacher from the New Zealand site never responded to inquiries about her lack of involvement in the online discussions. As such, we suspect that there are various reasons for the lack of participation from the teachers.

The initial posts of the majority of discussion threads $(90 \%, 118$ threads total) reflected the Climate Change Impacts and Mitigation of Climate Change groups. Nearly all discussion threads (98\%) reflected the interests of more than one of these groups, which were either conceptual (as primarily emphasized in the first IPCC working group) or socio-political (emphasized in the second and third working groups) in nature. Initial posts that targeted key information from the readings or class discussions (e.g., Based on the data we read today, it seems that the sea level is rising, but how fast will it rise?) were in turn followed by responses with a conceptual focus (reflecting the interests of the first IPCC working group) and with fewer emotional or personal narrative statements. Similarly, politicallycharged questions (e.g., How much does the government hide the truth about climate change?) were generally followed by points of view that were more political in nature (We have to keep the pressure on so that things will change). The discussion threads were fairly split between these two general interests. Occasionally, we observed the few comments that veered from topic of climate change ( $I$ have red hair); these comments were too few in number in order to observe any pattern involving their presence and thus were excluded from this study. 


\section{Dialogic action in climate change discussions: An international study of high school students in China, New Zealand, Norway and the United States}

Diana J. Arya \& Jessica K. Parker

\section{Results}

The facilitative moves of the participating scientists in this study (i.e., the assertions from participating scientists and the affordances of these assertions for supporting students' understanding) were traced across the 132 discussion threads, which began with a question or comment by a participating student and included all forms of subsequent responses (e.g. answers, comments, additional questions, embedded links, digital images, etc.). The results of our two-phase analytic approach indicate the following findings about the online discussion threads:

- Students demonstrated a high level of participation and engagement.

- Students rarely included scientific evidence (i.e., references to scientific findings) in their posts.

- Opinion statements without explanation or scientific evidence were not challenged.

- Facilitators, who were scientists and researchers, varied in their indication of membership (vs. authoritative voice) within the CELL community, unlike the students, who frequently acknowledged membership across the research sites.

Each of these findings is attested in turn by the following descriptive accounts of discussion threads.

\section{High-level Participation and Engagement}

As mentioned previously, participation in the discussion forums was not mandatory. Of the 141 students, 127 (90\% of the total) logged in to view discussions within at least one of the topics and 109 ( $77 \%$ of the total) posted at least one comment to one of the discussion threads. The fact that the majority of students were engaged to some degree with the discussion forums is consistent with responses from individual interviews in which the majority of participants (90\%) explicitly expressed an eagerness to learn more about climate change and about how people from other countries think about climate change issues, all of which speaks to the high level of engagement within this program.

The American students were most active, totaling in 43 contributors to the online forum $(30 \%$ of the total), with 27 Chinese and 23 Norwegian students also contributing to a fair amount of the exchange (19\% and $16 \%$ respectively). Only 16 New Zealand students contributed to these discussions (11\% of the total), which may be attributed to the fact that they entered the program two weeks after it began. Although participants from all countries contributed to the discussion threads, not all nationalities were represented in each thread.

All contributors to the online discussions posed predictions, questions, and/or declarations, all seemingly in an effort to voice their thoughts and elicit the thoughts of others involved in the project. All initial posts of the discussion threads were, by design, created by the participating students. Initiators' posts generally began with some commentary in reference to the classroom readings, an event or journalistic piece related to climate change, or to the author's worries and predictions about the plight of humanity and the animal kingdom, and finished with an elicitation for input from others.

There were no restraints on the nature or structure of participation in the discussion forums. The most common posts were variations on the question, What can we do? This demonstrated concern and reflection of the Mitigation of Climate Change discussion theme was also reflected in the individual interviews, during which the majority of students (approximately $80 \%, 87$ of the total 109 respondents) explicitly expressed a desire to do something that could either slow down or stop global climate change. 


\section{Dialogic action in climate change discussions: An international study of high school}

students in China, New Zealand, Norway and the United States

Diana J. Arya \& Jessica K. Parker

\section{Scientific Evidence (Not Opinion) as a Catalyst for Dialogic Action}

Student participants rarely presented scientific evidence in support of their conjectures about climate change. Of the total 310 individual student posts across the discussion threads, only 37 included the use of evidence in their explanations. Most other posts included either opinions without any explanations whatsoever, assumed shared knowledge (we all know that . . .) or personal narratives (well, I can see in my own country that . . . ) rather than the scientific evidence presented in the classroom readings. Of the 37 evidence-based posts, 27 focused predominantly on the working theme of the Physical Science Basis of Climate Change (based on the data table below, we know that the sea level is rising . . . ) with 10 posts highlighting Climate Change Impacts (in that report, we learned that emissions are causing the increase in CO2) and 8 posts referring to Mitigation of Climate Change (scientists reported that recycling would help a lot).

Our analysis of discussion threads revealed that posts in the form of more extensive reflections and explanations were most prevalent when there were disagreements to comments posted by one of the consulting scientists or researchers, or to students who cited scientific work. For example, comments that included references to scientific evidence presented in the readings (e.g., We read about how there's much more $\mathrm{CO} 2$ than ever before so it's pretty clear that people are making it worse) received far greater critical commentary (yeah but the weather is always changing and there is a natural cycle). These more extensive comments also demonstrated the use of hedging (i.e., observed reluctance or hesitancy to disagree, yes, I can see that, but . . ., e.g., Sacks, 1987). Posts that represented opinions or personal reflections without supportive evidence or references to external corroborating sources were left unchallenged.

\section{Indications of Membership within a Virtual Community}

Throughout the discussion threads, students used the first-person plural pronouns, us, we, our, $80 \%$ as often (a total of 540 entries) as first-person singular pronouns ( $I, m e, m y)$. The first-person plural pronouns were present in comments about potential courses of action (We should conserve our water use) and about problems relating to climate change (If people keep chopping down all the trees, our forests will be gone and the animals will die and we won't have any food). First-person singular pronouns were present in comments representing personal opinions about the current and future conditions of climate change (I think ... I believe that it is going to keep getting warmer) or personal experiences about courses of action (When I'm at home, I try to shut off the lights in other rooms ... .).

\section{Three Examples of Dialogic Action}

The following three discussion threads provide explanatory evidence for each of our findings described above. Each thread highlights one of each of the three themes (i.e., proposed courses of action, prospective claims about current and future conditions, and the universal relevance of climate change) that were selected during the first phase of our analysis. These threads illustrate our findings about students' commentaries and use of deictic markers (i.e., forms of communication that depend heavily on the given context; see Filmore, 1960; 1982) within the CELL online discussion forums. The first thread occurred during the first week of the program whereas the second and third threads occurred during the third and fourth weeks, respectively.

In order to protect the anonymity of the participants, all participants' names and references to specific places have been replaced by a pseudonym that maintains the cultural identity of participants. For example, the American participants whose actual names primarily reflected a Anglo-Saxon origin were given pseudonyms of a similar cultural quality while the Chinese participants were given 


\section{Dialogic action in climate change discussions: An international study of high school students in China, New Zealand, Norway and the United States}

Diana J. Arya \& Jessica K. Parker

pseudonyms that are conventional Chinese names. Individuals represented in the discussion threads are mostly students with the occasional commentary from a researcher (indicated by an asterisk, ${ }^{*}$ ) or a consulting scientist (indicated by two asterisks, ${ }^{* *}$ ). Students are able to view the profile of each contributor by clicking on the associated name, and, as mentioned earlier, scientists and researchers could be immediately identified by the fact that their last names were fully displayed.

The discussion threads are presented here as they were in the platform; original spelling and grammar are maintained, and any edits were solely for the purpose of masking identifying information beyond one's self-identified gender, nationality, and role in the program.

\section{Theme 1, courses of action.}

Respondents shared and considered a multitude of strategies for reversing, or at least slowing down, the effects of climate change. Contributions included references to national and local recycling programs, personal testimonies or declarations on reducing one's carbon footprint through the conservation of resources, and thoughts about alternative sources of energy. These contributions also reflected uncertainty about the state of affairs that may inform potential courses of action. One participant had posted the question, We need to fight climate change, but shouldn't we focus on our economy first? The following thread is an extended discussion about this issue of priority.

[Title of student-generated post]: What comes first, climate or economy?

Anders: In this blog i want to learn about what different pupils think about climate-change up against economy and cociety. Whats the most important at the moment? Shall we keep using coal and oil to save money or to focus on decreasing pollution and stop climate change? Or shall we do somthing in between? :-/ (This topic is also in my blogg) :-) next 6 weeks!

Donna*: Wow, great thoughtful questions ... I look forward to seeing your thinking develop over the

Arthur*: A great question, indeed. It seems like a lot of the people who don't want to think about climate change are the people involved in industries that generate a lot of pollution. Their argument is that the economy would suffer and jobs would be lost if they were forced to stop polluting so much. And to an extent, this is probably true. But maybe "greener" (more environmentally-friendly) industries can be developed, so that we don't need to choose between the economy and the environment?

Stian: Yes that is true, that would be great if we could find up "greener", more environmentally-friendly industries. But then again the economy cause a problem, because probably the new environmentally-friendly industries/factories will cost a lot of money and then few will choose these environmentally-friendly methodes.

Monica**: One thing I don't understand is why climate change in the US is framed as "it's either the environment or jobs". Personally, I don't believe that. Rather it is a tactic to scare people. Ultimately, without sustainable ecosystems we won't have sustainable economies....this is where efforts to value ecosystem services are trying to have an impact. Check out the Natural Capital Project.

Ying*: CLIMATE AND ECONOMY NEVER CONFLICT, the reason that causes the conflict is the nature of human beings---greed.

Anders: Yes greed and selfishness is one factor, but knowledge and influence by media/politicans can adjust how much a person cares about the climate and how much the person knows about what to do, whats happening ect. 


\title{
Dialogic action in climate change discussions: An international study of high school students in China, New Zealand, Norway and the United States
}

Diana J. Arya \& Jessica K. Parker

Anders: Comon I want more views here :-)

\begin{abstract}
Nicky*: I just heard a show on the radio that talked about how language can be used to make people feel differently about the same topic. Their example was that if you say "exploring for the environment" instead of "drilling for oil" you will get a much more positive response. Because there is so much pressure on big industry to be environmentally friendly and to address the issue of climate change, we really need to watch businesses carefully to make sure that what they are doing in the name of the environment is really good for the environment (and not just good for the economy).
\end{abstract}

Karl: I wish it was as easy as you present it [Ying], yet I have to disagree with you. In my opinion climate and economy DOES conflict with each other as of today. Although they did not come into conflict before about 1750 with the newly invented steam engine and the birth of pollution. From the late 1700's to about 1850 the industrial revulotion took place, and it changed the way we supported our lifestyle completely. From then on pollution have been with us every step of the way, and there is no other option when it comes manufacturing and farming. Pollution is there all along the way. This burden is weighing down on the economies shoulders whether they like it or not. Yet the question should be risen, in the end is it actually the market for such things that made it happen, and henceforth societies responsibility for supplying said market.So in a way I might agree with you Ying, but i would say that economy is responsible as for now. ;-)

Anders, a Norwegian student, began this thread by presenting the current economic conditions and the necessary actions for addressing the issues of climate change as opposing forces and thus sparking an exchange that seems largely socio-political in nature. The participating Norwegian teacher described Anders as an inquisitive student who is actively engaged in classroom activities. Donna and Arthur (both facilitating researchers) expressed general affirmations and compliments to Anders while the consulting scientist, Monica, engages in an open exchange about the problems of positioning climate change talk within a economy/climate debate structure. The contrast in facilitative styles demonstrated within this exchange highlight the issue of accolades and praise as a form of asserting authority within a learning community. Monica's use of phrases like "I don't understand ..." position her as a member of the CELL learning community rather than as an expert and a voice of authority.

Ying (a participating teacher) asserts her opinion that greed is the main reason for unresolved issues about climate change, and this comment is taken up by Anders and another Norwegian student, Karl, who push back on this stance. Both students first acknowledge the value in Ying's point and then present a more complex alternative to Ying's summation of the problem. Anders presents the notion of multiple factors preventing alternative industrial practices while Karl provides a brief historical narrative as evidence for the economy/climate conflict.

The dialogic action emerging from the posts in this discussion thread seems to be based on comments that are not positioned as authoritative frames; posts from facilitators (researchers, teachers, and scientists) that express questions, disagreements, opinions and the like invited contributions that engaged in the economic, socio-cultural, and political complexities of global climate change.

Scientific evidence is not emphasized in this discussion. Monica offers a source for further research on environmentally friendly industries that are cost-effective, but other references to authoritative knowledge (i.e., Karl's historical narrative and American researcher Nicky's reference to a radio show) are more speculative.

Theme 2, prospective claims.

As mentioned earlier, the study abstracts created and used in the CELL program were intended to be used by the participants in student-directed discussions about conceptual and social issues related to climate change. Reported current events, like the nuclear explosion in Japan that occurred during the implementation of this program, served as additional sources of knowledge for determining the 'truth' 


\section{Dialogic action in climate change discussions: An international study of high school students in China, New Zealand, Norway and the United States}

Diana J. Arya \& Jessica K. Parker

about the Earth's climate and potential demise. The following thread is an example of how $\mathrm{Ru}$, a Chinese student, integrates his understanding from the readings with the explosion in Japan to hypothesize about future conditions.

[Title of student-generated post]: Nuclear Explosion's influence to green house effect

Ru: Personally, I think the nuclear explosion of Japan may increase the temperature of the earth and it must be extremely harmful to people. What about your thoughts?

Nils: The nuclear explosion in Japan has nothing to do with an increase in temperature, and will not have any influence on the green house effect.

Jill: No Chernobyl is possible at a light water reactor. Loss of coolant means a temperature rise, but it also will stop the reaction. Even in the worst-case scenario, that would mean some radioactive leakage and equipment damage, but not an explosion. Read more: http://www.thefirstpost.co.uk/76237, newscomment,news-politics,japans-tsunami-and-nuclear-explosion-how-bad-is-it\#ixzz114WMj8MU

Anton: If the atomic plant in Japan has a meltdown, the possibility is close to slim that the temperature will rise. Radioactivity has got nothing to do with the global warming. The only place the plant will cause the environment is basically outside the plant. This is because the explosion will release a giant wave of heat. The climate will not be affected by this explosion.

This discussion took place a few days after a devastating earthquake in Japan. Ru, a Chinese student and considered by his teacher to be the highest performing in his class, speculates the possible climate-related consequences of the nuclear explosion and elicits other opinions. The post reflected many forum comments and blog entries from other Chinese students, who generally seemed more concerned about the Japanese earthquake than the other participants. The Chinese classroom teacher had mentioned that most of her conversations with the students during this time period centered on the Japanese earthquake.

Nils, a Norwegian student, dismisses Ru's prediction without any evidence or a rationale. Jill, an American student, and Anton, a Norwegian student, also refute Ru's claim and include media-related and conceptual knowledge to support their positions. Jill refers to the well-known disaster in Chernobyl and offers a link for further reading. Anton's use of the phrase "close to slim" reflects skepticism about a global rise in temperature. Unlike the previous thread, there seems to be no hedging or reluctance to disagree with $\mathrm{Ru}$. However, similar to the previous thread, the dialogic action emerging from this exchange opens the discussion to the complexities of disastrous events and to the possibility that resolutions are not as simple as they seem.

Theme 3, universal relevance of climate change.

Throughout the online discussions, students consistently used the pronouns, we, our and us. These deictic devices were used when speculating about current and future conditions and actions; student examples included: Are we destroying our planet? and What should we do about it? Deictic devices were also employed as declarations of assumed knowledge about human nature: We are naturally a compassionate species and our want to help sometimes has gotten us into trouble. The following thread highlights the recurring theme of the universal relevance of climate change.

[Title of student-generated post]: Isn't this just the way of nature?

Dialogic Pedagogy: An International Online Journal | http://dpj.pitt.edu

DOI: 10.5195/dpj.2015.53 | Vol. 3 (2015) 


\title{
Dialogic action in climate change discussions: An international study of high school students in China, New Zealand, Norway and the United States \\ Diana J. Arya \& Jessica K. Parker
}

\begin{abstract}
Sander: After taking a look at the scientist Siegenthalers diagram-that shows that the CO2-level has been going up and down in a 650,000 year period with pretty even spaces. Do we have to worry about that the CO2-level is rising? Because he supports (proves) that in a 650k year period it is just natural to think that the CO2-level will fall at some point, may not before 200 years from now. Isn't this just the way of nature?
\end{abstract}

Jason: I think CO2 is definitely something to worry about whether the world does it naturally or not.

Grace: Some of it could be caused by nature, but with the chemicals that humans use . . I believe it will just keep rising instead of going down. Millions of cars are made every year. And people keep getting another car, driving another car, and contributing to the atmosphere again.

Alice: True, but I think that we should still notice these problems.

Nate: It might be just the way of nature, but new modern technology has also caused an increase in $\mathrm{CO} 2$ and it will continue unless we do something about it.

Rose: We do play a part in the amount of $\mathrm{CO} 2$ because of the way we live in general but some of it's probably natural.

Thora**:That is an important question, and as a mater of fact, not all scientists agree on this. Several scientists wrote a report for the UN about the effects of releasing these gases. Research indicated that the effects were more sever than expected. For a short version of the report, see: http:/www.un.org/apps/news/story/asp?Cr=climate\&NewsID=21429

Molly** I think this technology/human impact idea is an interesting one. In architecture, we are often debating if we should look towards newer, more efficient technologies to reduce how much energy buildings use, or if we should look back to natural processes and try to design in ways that can use nature to be more sustainable - using wind to provide ventilation and re-using rainwater for tasks like flushing toilets. I'd be interested to hear what everyone thinks since it is a question without a clear answer - is technology making the greenhouse effect worse and/or do you think that more technology can help humans to reduce it?

The overall emphasis of this thread is concept-oriented; Sander, a Norwegian student, starts an exchange about one of the study abstracts that had been previously discussed in all of the participating classrooms. His question refers to the Figure 2, which was in the study abstract assigned for the week of the scheduled discussion. The figure is a graph that shows the combined results from an analysis of two ice cores (i.e., cylindrical samples of ice that are more than 2,000 meters in length); the graph shows shifts in levels of $\mathrm{CO} 2$ over a given time period, but no overall increase across this time period. 


\section{Dialogic action in climate change discussions: An international study of high school}

students in China, New Zealand, Norway and the United States

Diana J. Arya \& Jessica K. Parker

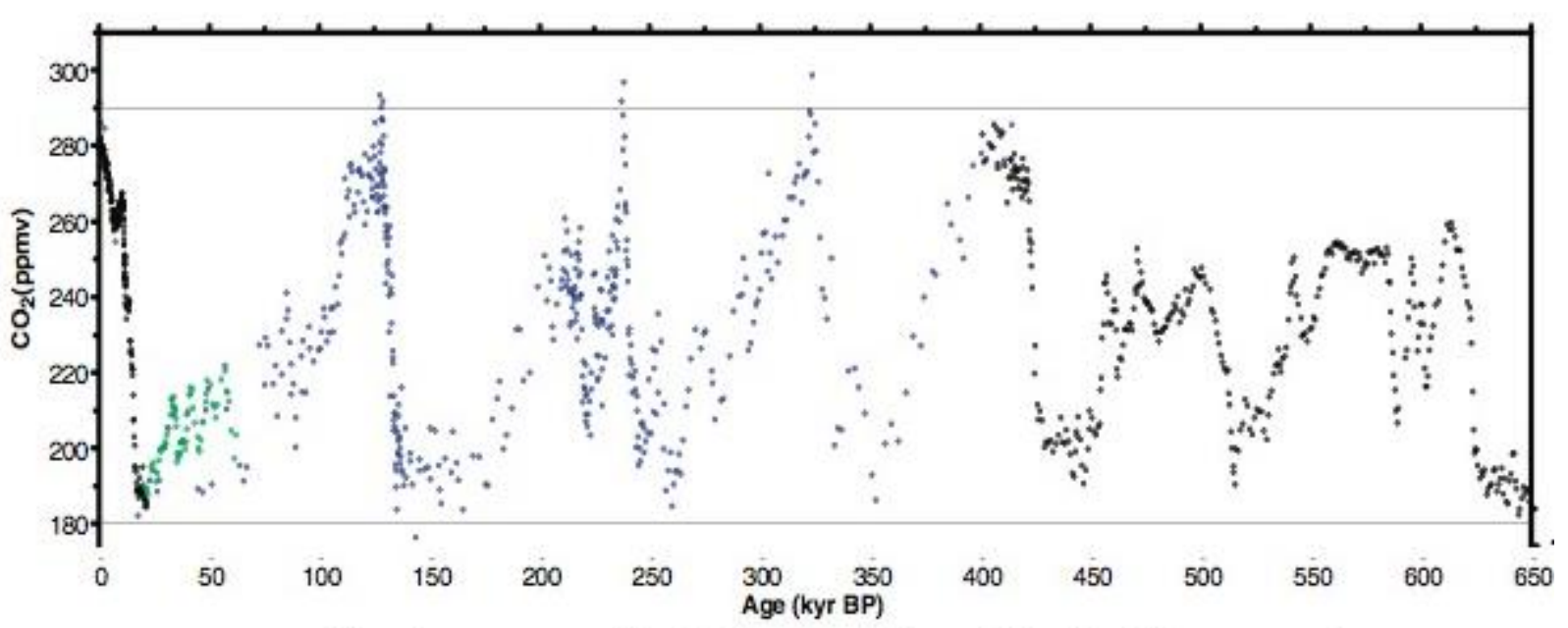

Timeline expressed in 1000 year units (e.g., $50=50,000$ years ago)

Figure 2. Fluctuations in $\mathrm{CO} 2$ levels in extracted ice core.

Sander refers to this table in his statement that levels of CO2 may decrease. Responses reflected a general acceptance of the plausibility of Sander's hypothesis, yet respondents are generally uncomfortable about the notion that we shouldn't worry about what cannot be changed. Jason and Alice, both American students, declare the need to worry or notice the documented trends of the climate. We observed similar comments throughout the discussion threads (e.g., well, we should be thinking about these things; we need to careful that we don't ignore these things), the bulk of which were posed by the American students. In the case for students who posted such comments, to pay attention to or to worry about the climate seems to be a form of taking action. Molly's commentary is the last post in this thread; although she encourages further discussion on the topic, no one picks up the topic. Both Thora and Molly (consulting scientists) indicate some notions of praise similar to the research facilitators featured in the first exchange. These authoritative voices are the last entries; the presence of dialogic action among the prior student exchange highlights the complexities of the rising level of carbon gases and their membership/responsibility to address these complexities.

American students Grace and Rose provide an explanation founded on assumed knowledge about human behavior: people are producing chemicals and driving cars, and this takes a toll on the atmosphere beyond the natural fluctuations, thus people must be contributing to the changes in the Earth's climate. Nate's reference to modern technology alludes to the additional, human-induced burden on the levels of $\mathrm{CO} 2$. The use of we in the student posts refers to all readers. Thus, there is an assumption that all members are affected by the consequences of increased levels of $\mathrm{CO} 2$ in the atmosphere, regardless of where they live in the world.

Although both scientists attempt to engage students in this discussion, the thread discontinues. Both begin with acknowledgement and praise for tackling tough issues like carbon emissions, which again could be interpreted as an assertion of an authoritative voice. Thora, a Norwegian astrophysicist, shares her knowledge about the ambivalence of the scientific community and offers counter-evidence in support of the hypothesis that even with the natural fluctuations, the current levels of various gasses are much greater than would be expected. Similarly, Molly, an American architect and scientist who studies sustainability efforts in developing countries, shares her experiences about the work she does with her 


\section{Dialogic action in climate change discussions: An international study of high school students in China, New Zealand, Norway and the United States}

Diana J. Arya \& Jessica K. Parker

colleagues. Both scientists, while attempting to open their professional experiences and knowledge to the CELL student community, are demonstrating their expertise as authoritative figures.

One consistent finding from our analysis is that instances of authoritative positioning are consistently absent in exchanges that feature dialogic action. The less posted comments or questions demonstrating authority (i.e., giving praise, or asserting professional status by describing one's work), the greater the presence of student questioning and challenging claims. Further, these instances of dialogic action revealed students' ability to grapple with complexities of climate change issues; students were able to address specific problems or processes within scientific, economic, political or socio-cultural contexts. Another finding that emerged from our analysis of dialogic action concerns the lack of scientific evidence in supporting or refuting claims raised in discussions. We address the pedagogical implications each of these findings in turn.

\section{Discussion}

An unavoidable limitation of text-based analyses of any kind is that one can only learn from what was said or written; it is not possible to learn about the thoughts and opinions of many of the participants who may have contributed as silent partners. It is also important to state our trepidations about conducting a discourse analysis of international data. Although we believe it is a worthwhile venture to study an online exchange between individuals from different parts of the world, we realize culture and contextualized genres are essential to communication and such intercultural communication may result in conflicts about what is expected from whom and to what particular ends (Kramsch \& Thorne, 2002). However, during our initial phase of categorizing discussion threads, we found that the student-driven discussion forums aligned succinctly with the official working groups established by the IPCC (2010), which was not entirely unexpected since the official materials and activities for the CELL program were inspired by the governing principles and published reports of IPCC. As such, we have some evidence, based on our successful taxonomy of discussion threads, that there was some communicative coherence in the online exchanges across the research sites.

With general limitations noted, three major general findings surfaced from our investigation of pedagogical moves for facilitating high school students' online interactions about climate change. First, our discourse analysis of interactions revealed that dialogic action was most prevalent in threads that invited multiple perspectives without authoritative assertions of praise or position. Second, we found that comments by students in these open exchanges often reflected a position that is more complex or nuanced than a purely dichotomous, agree/disagree response. Third, our concern about the lack of evidence used in assertions by students highlights a need to consider ways in which pedagogical moves can support evidence-based reasoning without inadvertently squelching the dialogic action needed for fostering deeper understanding. We unpack each of these findings according to our research questions.

\section{RQ1: Which assertions were taken up by students?}

The presence of authority in the form of evaluative comments (great response!) did not seem to inspire student engagement in dialogic action. Hermans and Dimaggio (2007) commented on the consequence of explicitly demonstrated differences in dominance between participants; when such differences

are minimal (as in a conversation between two good friends), the dialogical process is reciprocal, that is, the parties involved are relatively free ... [when] differences in dominance are strongly increased, questions 


\section{Dialogic action in climate change discussions: An international study of high school students in China, New Zealand, Norway and the United States}

Diana J. Arya \& Jessica K. Parker

and answers are highly uneven, with one party posing the questions and the other party forced to answer within the frame determined by the questioner as a representative of the institution. (p. 38)

Thus, pedagogical practices that strive to minimize difference in dominance-including refraining from evaluative comments during discussions-may help in increasing the dialogic action within student discussions.

Direct opinion statements or short refutations without references to external sources or personal narratives rarely received explicit negative evaluations of other students' viewpoints. For example, Nils's comment (The nuclear explosion in Japan has nothing to do with an increase in temperature, and will not have any influence on the green house effect) within the prospective claims thread reflects an opinion that is in direct opposition to Ru but without any direct comment about Ru's position (e.g., you're wrong; you don't have the correct information, etc.). Jill provided a website link that supports her position, which is also in opposition to $\mathrm{Ru}$, but beyond a brief negative marker, no, the focus in Jill's commentary remains on her own position. Thus, tensions in the form of negative address towards opposing opinions-tensions that are often observed in pundits' reports, oratories and blog posts (Bowman et al., 2010; Oreskes \& Conway, 2010)-were a rare occurrence in the discussion threads. The absence of such negative commentary may be in part due to the CELL discussion guideline that all members should be respectful and present their opinions without the use of negative or insulting commentary towards others. This expectation was introduced by the facilitators and teachers in the beginning of the program within the participating classrooms. Thus, we believe that establishing general community norms may be helpful to teachers who strive to create a safe place for dialogic exchanges about socially relevant issues like climate change.

\section{RQ2: How did the assertions support (or constrain) student contributions?}

Lengthier posts by students, as evidenced in the threads previously presented and discussed, often included conjectures with some reference to scientific evidence (e.g., reference to the readings), popular media (website links or reported current events), experiences (personal narratives), or assumed accepted knowledge (conventional social behaviors) and received responses with a similar level of reflection and references to external sources. Peer responses to student posts occasionally contained words or terms that would indicate some level of discomfort or hesitancy with a stance or opinion (e.g., yes, but; that may be true for you, but not for me), which more often is the case for disagreements during face-to-face interactions (Sacks, 1987). Such examples of hedging were observed in responses to comments that contained references to scientific information such as the classroom readings or a website presenting scientific data. Hedging was also observed when students were disagreeing with comments by researchers or scientists. Thus, an unanticipated form of tension within these discussion threads was the hedging used by contributors when addressing comments that referenced authoritative knowledge or that were written by authoritative figures (e.g., consulting scientists).

The dialogic tension observed in the extended contributions not only reflected some form of disagreement with other contributors but also some amount of ambivalence with one's own position or idea. For example, Karl's comment to Ying in the courses of action thread reflected a bit of hedging (I wish it is as easy as you present it; in a way I might agree with you), possibly due to Ying's more authoritative position as a researcher, and also demonstrated a more nuanced understanding of the economic and environmental issues related to climate change. Karl provided a historical context that was used to connect economic progress with pollution and to problematize Ying's simpler target of greed as reason that industrialized countries like the United States are not fully embracing mitigation strategies. 


\section{Dialogic action in climate change discussions: An international study of high school students in China, New Zealand, Norway and the United States}

Diana J. Arya \& Jessica K. Parker

Similarly, Grace and Nate considered multiple potential causes for climate change within the universal relevance discussion thread. Both students demonstrated hedging by acknowledging that the extreme observed conditions of the climate may be a part of the natural cycle (e.g., It might be just the way of nature,) but they followed with examples and assumed knowledge that targets humans as significant contributors to these conditions (Millions of cars are made every year; but new modern technology has also caused an increase in CO2). Such indications of uncertainty about future conditions and potential approaches for mitigating climate change effects seem to align with the work of Hermans and Dimaggio (2007), who traced the dialogic nature of self and identity for individuals living in increasing globalization and uncertainty. These scholars make visible the multiple voices within a person, and the need for the development of a "dialogic self" (Hermans \& Hermans-Konopka, 2010) to engage in the complexities of global and local contexts. Instances of hedging may be one way that participants negotiate these multiple voices. We believe that one consideration for dealing with uncertainty is for teachers or facilitators with subject matter expertise to model this uncertainty in their own thinking; just as Monica, the science consultant within the first featured exchange, indicated her lack of understanding and discomfort about the framing of climate change as a debate, science teachers could also share their confusions, or even conflicting ideas about various concepts and processes.

One of the most problematic findings from our investigation is the lack of discussion about scientific evidence. According to the Next Generation Science Standards (Achieve Inc., 2013), which were drafted by the contributive efforts of 26 states within the U.S., students must have opportunities to engage in discussions about scientific evidence. The fact that students read and discussed study abstracts related to climate change concepts and processes was apparently insufficient for inspiring student-led, online discussion anchored to scientific evidence. Related research on scientific argumentation suggests two approaches for effectively fostering evidence-based discussions; one approach involves explicit teaching of Toulmin-like, argumentative structures used in explaining data or supporting conjectures with evidence (e.g., Sadler \& Donnelly, 2006; Simon, Erduran \& Osborne, 2006; Toulmin, 1969) while the other approach involves the use of open-ended questions that give students the opportunity to question and explain scientific evidence within a social context (Lee \& Kinzie, 2012; Smart \& Marshall, 2013). Findings from this study suggest that perhaps an open design allowing more expressions of uncertainty may be helpful for providing students opportunities to consider the complexities of concepts and processes related to socio-scientific issues like climate change. We suggest that time, space and an open invitation to engage in such issues may serve an important first stage in the development of arguments, which does not fit within a clearly defined linear structure (Sadler \& Donnelly, 2006; Sadler \& Fowler, 2006). Future iterations of CELL should include explicit structures for teachers and other facilitators as co-learners and models for engaging in the uncertainty of issues that connect participants across local and global spaces (Krueger, 2000). This point is supported by our finding no significant differences in growth in student participants' understanding (using pre- and post- interview responses) about uncertainty when asked about the role of scientific evidence in asserting claims. Extended invitations for students to evaluate the varying qualities of evidence, and what counts as "compelling" should be considered.

The programmatic features of CELL may have supported constructive discourse about climate change-related science and issues; however, further refinements in this initiative should include ways in which such online exchanges could lead to furthering community-based understanding about climate change. Some educational scholars like Wells (1999) suggest that an online discussion forum may not be the most appropriate source for investigating intellectual development through dialogic action; our findings seem to align with this position in that none of the discussion threads in this study included a declaration or demonstration of new understanding. Scardamalia and Bereiter (2006) found similar results 


\section{Dialogic action in climate change discussions: An international study of high school students in China, New Zealand, Norway and the United States}

Diana J. Arya \& Jessica K. Parker

with the use of discussion forums and concluded that the discussion-thread format may actually hinder a group's ability to build a shared understanding about targeted conceptual knowledge. However, what are better sources? We argue that forums with open-ended prompts that minimize the differences in authoritative positions are precisely a medium needed to ensure student engagement and membership in scientific discussions, and with sufficient support in ways to engage in the uncertainties and complexities of climate change science, student contributors would demonstrate growth in collective understanding.

Findings from this study suggest that when students have the opportunity to engage in thoughtful, open discussions about matters of importance, like climate change, a variety of forces have a potential influence in what individuals bring to the discussion and that tensions between and within contributors reflect a complex level of understanding rather than a one-sided, polarized view of climate change. Participants in the CELL program demonstrated their ability to use the variety of funds of knowledge (Moll et al., 1982) that are available to them while engaging in meaningful discussions about subjects that matter. Unlike traditional classrooms, all members in an online exchange had the opportunity to share their thoughts and insights, which can result in more critically engaged discussions. These participants also demonstrated their willingness to venture into the grey areas of climate change rather than hold onto ideological positions. However, moments of authoritative assertions as demonstrated in the sampled discussion threads reveal the need for pedagogical practices that minimize the differences in authority in order to foster the dialogic action needed for civic engagement in climate change issues (Buckler \& Creech, 2014). Students are able to handle the realistic complexities of socio-political issues and teachers, educators, and members of professional communities should acknowledge and use these abilities for fostering exchanges that address the complexities of issues like climate change. Further efforts to support online discussions about scientific evidence are also needed in order to align with the current demands of school science curricula (Achieve, Inc., 2013).

The implications from this study highlight the need for dialogic pedagogical practices to include community-based approaches in which students share, debate, and reflect on their scientific knowledge and inquiries as active student-researchers in a complex world of science, politics, and socio-economic issues. Such discursive practices broaden the focus of study to acknowledge the multiple contexts of science exploration and the relevant issues related to socially-relevant scientific topics like climate change. Additionally, an online space complementing a face-to-face classroom environment can potentially foster international connections that reflect complex, nuanced positions rather than polarized viewpoints. Pedagogical practices that support dialogic action position the teacher or facilitator as a colleague rather than an expert with authority; opening discussions to uncertainty and unknown futures may further spur the dialogic positioning across and even within student participants. Although the teachers in this study were not actively participating in the online discussions, the instances of experts positioning themselves as colleagues demonstrates this potential. Future research efforts should include the investigation of how such complex exchanges about socially and culturally relevant topics and issues can foster collective understanding.

\section{References}

Abd-El-Khalick, F., Boujaoude, S., Duschl, R., Lederman, N. G., Mamlok-Naaman, R., Hofstein, A., ... \& Tuan, H. L. (2004). Inquiry in science education: International perspectives. Science Education, 88(3), 397-419.

Ackerson, V.L. and Abd-El-Khalick, F.S. (2005). "How should I know what scientists do? I'm just a kid": Fourth-grade students' conceptions of nature of science. Journal of Elementary Science Education, 17(1), 1-11. 


\section{Dialogic action in climate change discussions: An international study of high school students in China, New Zealand, Norway and the United States}

Diana J. Arya \& Jessica K. Parker

Achieve, Inc. on behalf of the twenty-six states and partners that collaborated on the NGSS (2013). Next Generation Science Standards. Achieve, Inc. on behalf of the twenty-six states and partners that collaborated on the NGSS. Captured from: http://www.nextgenscience.org/next-generationscience-standards.

Adair-Hauck, B., Donato, R., \& Cumo, P. (1994). Using a whole language approach to teach grammar. In J. Schrum \& E. Glisan (Eds.), Contextualized foreign language instruction K-12 (pp. 90-111). Boston: Heinle.

Anderson, T. (2008). Towards a theory of online learning. In T. Anderson (Ed.) Theory and practice of online learning ( $2^{\text {nd }}$ Edition) (pp. 45-74) Alberta Canada: AU Press.

Anton, M. (1999). The discourse of a learner-centered classroom: Sociocultural perspectives on teacherlearner interaction in the second-language classroom. The Modern Language Journal, 83(3), 303318.

Atkinson, J.M. \& Heritage, J. (1984). Structures of social action. Cambridge: Cambridge University Press.

Bakhtin, M. M. (1930s/1981). The dialogic imagination: Four essays. Ed. Michael Holquist. Trans. Caryl Emerson \& Michael Holquist. Austin and London: University of Texas Press.

Bazerman, C. (1982). Scientific writing as a social act: A review of the literature of the sociology of science. In P. V. Anderson, J. Brockman, \& C. R. Miller (Eds.)In P. V. Anderson, J. Brockman, \& C. R. Miller (Eds.), New essays in technical and scientific communication: Research, theory, and practice (pp. 156-84). Farmingdale, NY: Baywood.

Bell, P. (1997). Using argument representations to make thinking visible for individuals in groups. Proceedings of the Computer Supported Clever to Learning Conference (pp. 10-19). Toronto, Canada: University of Toronto.

Bellanca, J. A., \& Stirling, T. (2011). Classrooms without borders: Using Internet projects to teach communication and collaboration. Teachers College Press.

Benavot, A. 2014. Education for Sustainable Development in Primary and Secondary Education. Background paper for the DESD Global Monitoring Report 2014. (Unpublished.)

Beth, A. D., Jordan, M. E., Schallert, D. L., Reed, J. H., \& Kim, M. (2013). Responsibility and generativity in online learning communities. Interactive Learning Environments, (ahead-of-print), 1-14.

Blake, R. J. (2013). Brave new digital classroom: Technology and foreign language learning. Georgetown University Press.

Bomer, K. \& Bomer, R. (2001). For a better world: Reading and writing for social action. Portsmouth, NH: Heinemann.

Budowle, B., Bottrell, M. C., Bunch, S. G., Fram, R., Harrison, D., Meagher, S., ... \& Stacey, R. B. (2009). A Perspective on Errors, Bias, and Interpretation in the Forensic Sciences and Direction for Continuing Advancement*. Journal of Forensic Sciences, 54(4), 798-809.

Bowman, T.E. et al. (2010). Letters: Time to take action on climate communication. Science Magazine, 19, November, p. 1044.

Buckler, C. \& Creech, H. (2014). Shaping the future we want: UN decade of education for sustainable development. Luxembourg: UNESCO. 


\section{Dialogic action in climate change discussions: An international study of high school students in China, New Zealand, Norway and the United States}

Diana J. Arya \& Jessica K. Parker

Cartwright, N. (1983). How the laws of physics lie. UK: Oxford University Press.

Cho, Y. H., Lee, J., \& Jonassen, D. H. (2011). The role of tasks and epistemological beliefs in online peer questioning. Computers \& Education, 56(1), 112-126.

Church, J.A. \& White, N.J. (2006). A 20th century acceleration in global sea-level rise. Geophysical Research Letters, 33, 1-4.

Cohen, A., \& Scardamalia, M. (1998). Discourse about ideas: Monitoring and regulation in face-to-face and computer-mediated environments. Interactive Learning Environments, 6(1-2), 93-113.

Collins, A., \& Halverson, R. (2009). Rethinking education in the age of technology: The digital revolution and schooling in America. Teachers College Press.

Cress, U., \& Kimmerle, J. (2008). A systemic and cognitive view on collaborative knowledge building with wikis. International Journal of Computer-Supported Collaborative Learning, 3(2), 105-122.

Enyedy, N. \& Hoadley, C.M. (2006). From dialogue to monologue and back: Middle spaces in computermediated learning. International Journal of Computer-Supported Collaborative Learning, 1(4), 413-439.

Fien, J. 2012. Learning for a Sustainable Future: Maximizing the synergies between quality education, learning and sustainable human development. A paper prepared by Professor John Fien (RMIT University, Australia) on behalf of the Inter- Agency Committee for the UN Decade of Education for Sustainable Development.

Flanders, N. (1970). Analyzing teacher behavior. Reading, MA: Addison-Wesley.

Freire, P. (1970). Pedagogy of the oppressed. New York: Continuum.

Gee, J. P. (1996). Social linguistics and literacies: Ideology in Discourses (2 ${ }^{\text {nd }}$ ed). London: Taylor \& Francis.

Giere, R. (1988). Explaining science. Chicago: University of Chicago Press.

Gleick et al. (2010). Letters: Climate change and the integrity of science. Science Magazine, 7 May, 689.

Gutiérrez, K. D., Baquedano-López, P., \& Tejeda, C. (1999). Rethinking diversity: Hybridity and hybrid language practices in the third space. Mind, culture, and activity, 6(4), 286-303.

Hafner, C., \& Miller, L. (2011). Fostering learner autonomy in English for science: A collaborative digital video project in a technological learning environment. Language Learning and Technology, 15(3), 68-86.

Hermans, H. J., \& Dimaggio, G. (2007). Self, identity, and globalization in times of uncertainty: a dialogical analysis. Review of general psychology, 11(1), 31.

Hermans, H., \& Hermans-Konopka, A. (2010). Dialogical self theory: Positioning and counter-positioning in a globalizing society. Cambridge University Press.

Hernández-Ramos, P. (2004). Web logs and online discussions as tools to promote reflective practice. The Journal of Interactive Online Learning, 3(1), 1-16.

Hicks, D. (1996). Contextual inquiries: A discourse-oriented study of classroom learning. In D. Hicks (Ed.), Discourse, learning, and schooling (pp. 104-144). New York: Cambridge University Press. 


\section{Dialogic action in climate change discussions: An international study of high school students in China, New Zealand, Norway and the United States}

Diana J. Arya \& Jessica K. Parker

Hoadley, CM, \& Enyedy, N. (1999). Between information and communication: Middle spaces in computer media for learning. In C. Hoadley \& J. Roschelle (Eds.), Proceedings of the Computer Support for Collaborative Learning (CSCL) 1999. ACM Digital Library. Retrieved from http://dl.acm.org/citation.cfm?id=1150270

Hoadley, C. M. \& Linn, M. C. (2000). Teaching science through online, peer discussions: Speak easy in the knowledge integration environment. International Journal of Science Education, 22(8), 839857.

Hoskins, S. L., \& Van Hooff, J. C. (2005). Motivation and ability: which students use online learning and what influence does it have on their achievement?. British Journal of Educational Technology, 36(2), 177-192.

Intergovernmental Panel on Climate Change (IPCC, 2010). Retrieved from http://www.ipcc.ch/

Kelly, G.J. \& Chen, C. (1999). The sound of music: Constructing science as sociocultural practices through oral and written discourse. Journal of Research in Science Teaching, 36(8), 883-915.

Kop, R. (2011). The challenges to connectivist learning on open online networks: Learning experiences during a massive open online course. The International Review of Research in Open and Distance Learning, Special Issue-Connectivism: Design and Delivery of Social Networked Learning, 12(3).

Kramsch, C. \& Thorne, B. (2002). Foreign language learning as global communicative practice. In D. Block and D. Cameron (Eds.), Globalization and language teaching (pp. 83-100). London: Routledge.

Kreijns, K., Kirschner, P. A., \& Vermeulen, M. (2013). Social aspects of CSCL environments: A research framework. Educational Psychologist,48(4), 229-242.

Krueger, J. (2000). Distributive judgments under uncertainty: Paccioli's game revisited. Journal of Experimental Psychology: General, 129(4), 546.

Larusson, J. A., \& Alterman, R. (2009). Wikis to support the "collaborative" part of collaborative learning. International Journal of Computer-Supported Collaborative Learning, 4(4), 371-402.

Latour (1987). Science in action. Cambridge, MA: Harvard University Press.

Lederman, N.G. (1992). Students' and teachers' conceptions of the nature of science: A review of the research. Journal of Research in Science Teaching, 29(4), 331-359.

Lee, Y., \& Kinzie, M. B. (2012). Teacher question and student response with regard to cognition and language use. Instructional Science, 40(6), 857-874.

Lemke, J. (1990) Talking science: Language, learning, and values. Norwood, NJ: Ablex Publishing.

Lewis, C. (2001). Literary practices as social acts: Power, status, and cultural norms in the classroom. Mahwah, NJ: Erlbaum.

Luke, A. (2008). Pedagogy as gift. In J. Albright and A. Luke (Eds.), Pierre Bourdieu and literacy education (pp. 68-91). New York, NY: Routledge.

Luke, A., \& Woods, A. (2009). Policy and adolescent literacy. In L. Christenbury, R. Bomber and P. Smagorinsky (Eds.), Handbook of adolescent literacy research (pp.197-219). New York: Guilford Press. 


\section{Dialogic action in climate change discussions: An international study of high school students in China, New Zealand, Norway and the United States}

Diana J. Arya \& Jessica K. Parker

Mak, B., \& Coniam, D. (2008). Using wikis to enhance and develop writing skills among secondary school students in Hong Kong. System, 36(3), 437-455.

Massy, J. (2003). Quality and eLearning in Europe: Summary report 2002. Reading: Bizmedia.

Mazur, J. (2004). Conversation analysis for educational technologists: theoretical and methodological issues for researching the structures, processes and meaning of on-line talk. In D. H. Jonassen (Ed.), Handbook for Research in Educational Communications and Technology, 2nd Edition (pp. 1073-1098). Mahwah, NJ: Lawrence Erlbaum Associates.

Mendelsohn, E. (1977). The social construction of scientific knowledge. In E. Mendelsohn, P. Weingart and R. Whitley (eds.), The Social Production of scientific knowledge: Sociology of the sciences (pp. 3-26). Dordrecht: D. Reidel.

Mills, K. A. (2009). Multiliteracies: Interrogating competing discourses. Language and Education, 23(2), 103-116.

Moll, L. C., Amanti, C., Neff, D., \& Gonzalez, N. (1992). Funds of knowledge for teaching: Using a qualitative approach to connect homes and classrooms. Theory into practice, 31(2), 132-141.

Mortimer, E.F. \& Scott, P.H. (2003). Meaning making in secondary science classrooms. Maidenhead, PA: Open University Press.

Nersessian, N. J. (1999). Model-based reasoning in conceptual change. In Magnani, L., Nersessian, N. J., \& Thagard, P. (eds.) Model-Based Reasoning in Scientific Discovery (pp. 5-22). New York: Kluwer Academic/Plenum Publishers.

Nussbaum, E. M., Winsor, D. L., Aqui, Y. M., \& Poliquin, A. M. (2007). Putting the pieces together: Online argumentation vee diagrams enhance thinking during discussions. International Journal of Computer-Supported Collaborative Learning, 2(4), 479-500.

Oreskes, N. \& Conway, E. M. (2010). Defeating the merchants of doubt. Nature, 465(7299), 686-687.

Pifarre, M. \& Staarman, J.K. (2011). Wiki-supported collaborative learning in primary eduation: How a dialogue space is created for thinking together. Computer-Supported Collaborative Learning, 6(2), 187-205.

Pomerantz, A. (1984). Pursuing a response. In J. M. Atkinson \& J. Heritage (Eds.), Structures of social action (pp. 152-163). Cambridge: Cambridge University Press.

Richardson, J. C., \& Swan, K. (2003). Examining social presence in online courses in relation to students' perceived learning and satisfaction. Journal of Asynchronous learning networks, 7(1), 68-88.

Rourke, L., \& Kanuka, H. (2007). Barriers to online critical discourse. International Journal of ComputerSupported Collaborative Learning, 2(1), 105-126.

Rovai, A. P., \& Jordan, H. (2004). Blended learning and sense of community: A comparative analysis with traditional and fully online graduate courses. The International Review of Research in Open and Distance Learning, 5(2).

Sacks, H. (1987). On the preferences for agreement and contiguity in sequences in conversation. In G. Button and J.R.E. Lee (Eds.), Talk and social organization, (pp. 54-69). Avon, England: Multilingualim Matters.

Sadler, T. D., \& Donnelly, L. A. (2006). Socioscientific argumentation: The effects of content knowledge and morality. International Journal of Science Education, 28(12), 1463-1488. 


\section{Dialogic action in climate change discussions: An international study of high school students in China, New Zealand, Norway and the United States}

Diana J. Arya \& Jessica K. Parker

Sadler, T. D., \& Fowler, S. R. (2006). A threshold model of content knowledge transfer for socioscientific argumentation. Science Education, 90(6), 986-1004.

Sampson, V., \& Clark, D. B. (2009). The impact of collaboration on the outcomes of scientific argumentation. Science Education, 93(3), 448 - 484.

Scardamalia, M., \& Bereiter, C. (2006). Knowledge building: Theory, pedagogy, and technology. In K. Sawyer (Ed.), Cambridge Handbook of the Learning Sciences (pp. 97-118). New York: Cambridge University Press.

Scott, P. H. (1998). Teacher talk and meaning making in science classrooms: A Vygotskian analysis and review. Studies in Science Education, 32(1), 45-80.

Schellens, T. \& Valcke, M. (2005). Collaborative learning in asynchronous discussion groups: What about the impact on cognitive process? Computers in Human Behavior, 21(6), 957-975.

Simon, S., Erduran, S., \& Osborne, J. (2006). Learning to teach argumentation: Research and development in the science classroom. International Journal of Science Education, 28(2-3), 235260.

Slotta, J.D. \& Aleahmad, T. (2009). WISE technology lessons: Moving from a local proprietary to a global open source framework. Research and practice in technology enhanced learning, 4(2), 169-189.

Slotta, J., \& Linn, M. C. (2009). WISE Science: Web-based inquiry in the classroom. New York: Teachers College Press.

Smart, J. B., \& Marshall, J. C. (2013). Interactions Between Classroom Discourse, Teacher Questioning, and Student Cognitive Engagement in Middle School Science. Journal of Science Teacher Education, 24(2), 1-19.

Stagg Peterson, S. \& Slotta, J.D. (2009). Saying yes to online learning: a first-time experience teaching an online graduate course in literacy education. Literacy Research and Instruction, (48)2, 120136.

Sutton, C. (1996). Beliefs about science and beliefs about language. International Journal of Science Education, 18(1), 1-18.

Toulmin, S. (1969). The uses of argument. Reprint, New York: Cambridge. [Originally published 1958]

Vygotsky, L.S. (1978). Mind in society. Cambridge, MA: Harvard University Press.

Wals, A. E. (2012). Shaping the education of tomorrow: 2012 full-length report on the UN decade of education for sustainable development. Paris, France: UNESCO.

Wells, G. (1999). Dialogic inquiry: Towards a sociocultural practice and theory of education. New York: Cambridge University Press.

Wegerif, R. (2006). A dialogic understanding of the relationship between CSCL and teaching thinking skills. Computer-Supported Collaborative Learning, 1, 143-157.

Wegerif, R. (2004). The role of educational software as a support for teaching and learning conversations. Computers \& Education, 43(1-2), 179-191.

Wegerif, R. (2011). Towards a dialogic theory of how children learn to think. Thinking Skills and Creativity, 6(3), 179-190. 


\section{Dialogic action in climate change discussions: An international study of high school}

students in China, New Zealand, Norway and the United States

Diana J. Arya \& Jessica K. Parker

Wegerif, R., McLaren, B. M., Chamrada, M., Scheuer, O., Mansour, N., Mikšátko, J., \& Williams, M. (2010). Exploring creative thinking in graphically mediated synchronous dialogues. Computers \& Education, 54(3), 613-621.

Wertsch, J. (2002). Voices of collective remembering. New York: Cambridge University Press.

Wertsch, J. (2002). Commentary: Computer mediation, PBL and dialogicality. Distance Education, 23(1), 105-108.

Wheeler, S., Yeomans, P., \& Wheeler, D. (2008). The good, the bad and the wiki: Evaluating studentgenerated content for collaborative learning. British Journal of Educational Technology, 39(6), 987-995.

Zander, M.J. (2003). Talking, thinking, responding and creating: A survey of literature on talk in art education. Studies in Art Education, 44(2), 117-134.

\section{(cc) EY}

New articles in this journal are licensed under a Creative Commons Attribution 4.0 United States License.

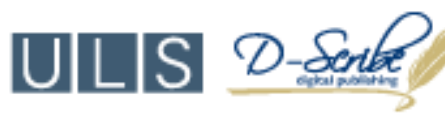

This journal is published by the University Library System, University of Pittsburgh as part of its D-Scribe Digital Publishing Program and is cosponsored by the University of Pittsburgh Press. 